\title{
Response of Life History and Enzyme Biomarkers in Oligochaete Earthworm Due to Synthetic Pyrethroid Contamination: An Ecotoxicological Study
}

\author{
Somanka Sanyal ${ }^{1 *}$ and Partha Pratim Chakravorty ${ }^{2}$ \\ ${ }^{1}$ International Institute of Innovation and Technology, 01-0317, DH-6/24, DH Block (Newtown), Action Area 1D, Kolkata, West \\ Bengal, India. ${ }^{2}$ Post Graduate Department of Zoology, Raja Narendra Lal Khan Women's College, Gope Palace, Medinipur, Vidyasagar \\ University Road, West Bengal, India.
}

\begin{abstract}
Environmental conservation has been a burning topic for the past few decades and conservation and health monitoring of soil and soil biota is a domain that needs to be dealt with which is directly related to agriculture, food and human health. Due to indiscriminate of chemical fertilizers the soil health and the ecology of soil organisms has been drastically deteriorated. Beneficial non-target organisms are harmed as a result of pesticide application, earthworms being the most common and abundant amongst them. Cypermethrin is one of the commonly used synthetic pyrethroid pesticides in agricultural field. Perionyx excavatus is an indigenous species of epigeic earthworm found in abundance in the uncultivated grasslands, around Midnapore district of West Bengal, that are free from direct pesticide contamination and are collected from there. In this study, acute toxicity of selected earthworms was evaluated following the 96-hr LC $_{50}$ test under laboratory conditions. Similarly, chronic toxicity of preclitellete and adult earthworms Perionyx excavatus was evaluated by exposing them to sublethal concentrations i.e. $25 \%$ of $\mathrm{LC}_{50}$ (T1) and $50 \%$ of $\mathrm{LC}_{50}$ (T2) of cypermethrin (Cypermethrin- T1- $3.0 \mu \mathrm{g} / \mathrm{kg}$ soil, $\mathrm{T} 2-6.0 \mu \mathrm{g} / \mathrm{kg}$ soil) for 28 days to detect their developmental changes and changes in cellular enzyme activities respectively, under laboratory conditions. Our results showed that cypermethrin could lead to significant reduction of biomass, reduced cocoon production and changes in acid and alkaline phosphatase activity. We found that in case of T2 sublethal dose of cypermethrin cocoon production was reduced to nil. In summary, we found that cypermethrin induced both developmental and enzymatic changes in Perionyx excavatus, contributing to a more comprehensive evaluation of the safety of the synthetic pyrethroid. These parameters can also be used as effective tools in detecting pesticide pollution in agro-ecosystems.
\end{abstract}

Keywords: Cypermethrin, synthetic pyrethroid, alkaline phosphatase, natural soil, acute toxicity.

\section{INTRODUCTION}

Soil pollution has risen to an alarming level for the last few decades due to excessive agricultural use of pesticides and fertilizers. As a result, soil aeration and its fertility has faced a change further leading to an imbalance between flora and fauna residing in the soil $(1,2)$. Along with its flora and fauna, soil is a complex mixture of minerals and organic matter. Therefore, being the main consumers and decomposers of soil ecosystem, the soil quality management depends much on its fauna (3). Earthworms act as excellent bio-indicator helping in the evaluation of the health status of soil ecosystem. It has been indicated by earlier

*Address of Correspondence: Dr. Somanka Sanyal, Research Scientist, International Institute of Innovation and Technology, 01-0317, DH-6/24, DH Block (Newtown), Action Area 1D, Kolkata, West Bengal, India.

E-mail-somanka85@gmail.com

(Received 25 August 2020; revised 15 September 2020; accepted 21 September 2020) 
reports that pesticide application pose threat to their lives as they are exposed to soil contaminated by pesticides (4). They constitute up to $92 \%$ of the invertebrate biomass in the soil and become easily susceptible to pesticides applied in agricultural fields (5). Susceptibility and sensitivity to the soil pollutants in earthworms is much more as compared to other soil inhabitants (6). Therefore, for studying the pesticidal impacts on their stress related biochemical parameters, they are considered most suitable organisms.

Cypermethrin is a broad-spectrum insecticide used to control agricultural pests and have been listed as pesticides of potential concern by the US National Oceanic and Atmospheric Administration $(7,8)$. Synthetic pyrethroids are used to control insect pests in agriculture, homes, communities, hospitals, schools and to treat topical head lice and scabies (9). In urban areas pyrethroids are applied primarily for structural pest control, while in agricultural areas these are applied on row crops and orchards, and these insecticides are also used for various household and veterinary purposes $(10,11)$. Goulart and Callisto, 2003 mentioned that non-target species and other factors are contaminated by the pesticides used in agricultural fields (12). Miller, 2004 reported that the quantum of the sprayed pesticides that reach to these non-target destinations is as high as $98 \%$ (13).

In the present study, synthetic pyrethroid cypermethrin $\quad(10 \% \quad$ EC) ([Cyano-(3phenoxyphenyl) methyl]3-(2,2dichloroethenyl)2,2-dimethylcyclopropane-1-carboxylate;

PubChem CID: 2912]) was used for acute and sub-lethal toxicity in indigenous species of earthworm, Perionyx excavatus. The life history and bio chemical markers in this experiment have been studied to evaluate the impact of the pyrethroid on the earthworm. 96hr acute toxicity method [Organization for Economic Cooperation and Development (OECD) guidelines, 207] (14) and 28-day chronic toxicity method (15) were implemented to assess the impact of the pesticide on the earthworm.

\subsection{MATERIALS AND METHODS}

\subsection{Test organisms}

In India, there are about little more than 500 species of earthworms (16). Seventeen species belonging to 2 orders, 6 families, 13 genera are found in Midnapore district of West Bengal (17). The epigeic earthworm Perionyx excavatus (Figure 1), which was selected as the test organism for this study, is a common species in India and of the Midnapore district.

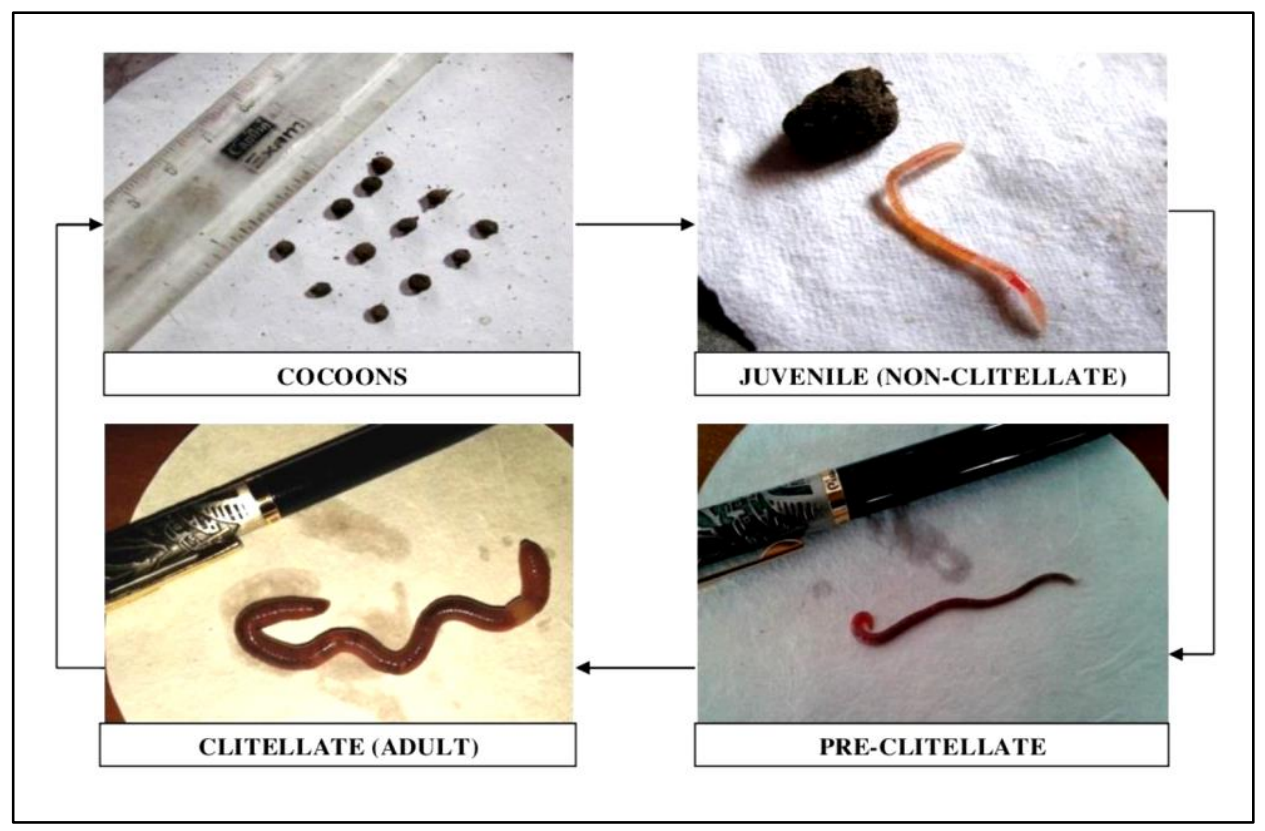

Figure 1: Stages of the life history of Perionyx excavatus 


\subsubsection{Collection, culture and maintenance}

The test specimens were collected from the grasslands of Midnapore district (Figure 2) that do not have any history of direct pesticide application. Cool, moist and shady areas were chosen for collection of specimens. Soil was dug up to a depth of at least $12-16 \mathrm{~cm}$ with the help of a hand spade and the specimens were collected in plastic bags with little amount of moist soil and they were brought to the laboratory for identification and culture (18).

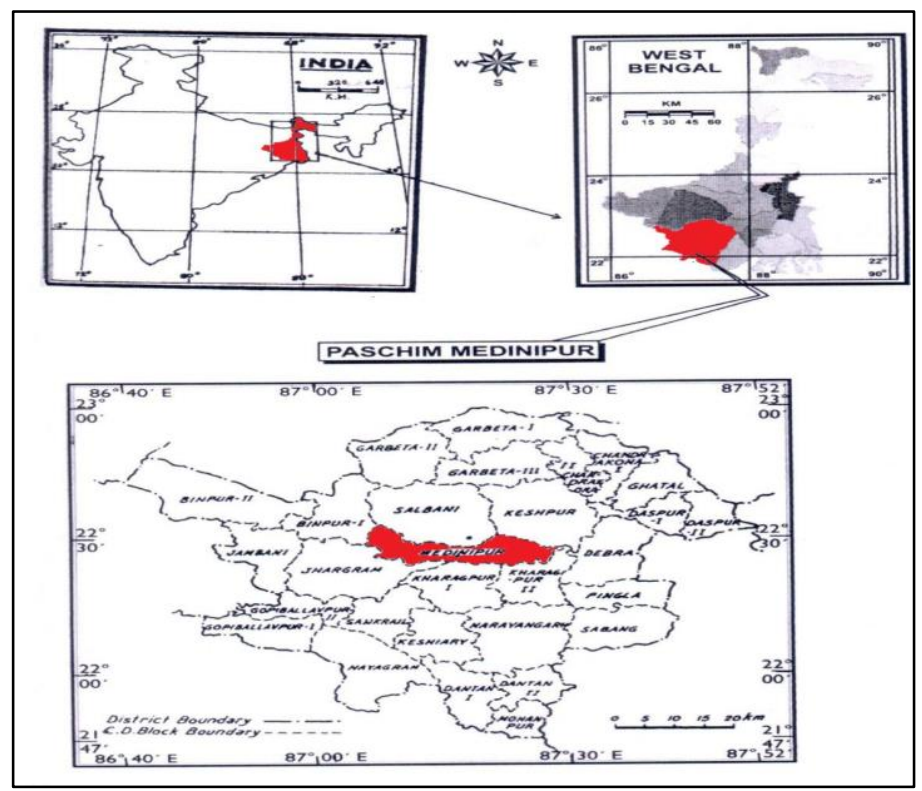

Figure 2: Site of specimen collection

In the laboratory, large cement vats (Figure 3) were used for the culture of earthworms. Soil used for the medium was collected from the same grasslands as of the specimens. A mixture was prepared with finely ground soil and farmyard manure in the ratio 1:1 and was used as the culture medium for the specimens (19). The vats were covered with fine meshed iron nets. An approximate level of 50-60\% moisture was maintained in the medium by adding distilled water. Dried and ground farmyard manure was added as food for the earthworms every week during the entire culture period. Cocoons were then hand sorted and examined, placed in separate experimental pots for use as test specimens in the experiments following
OECD guidelines $(14,15)$.

\subsection{Test Media}

Grassland soil was collected from the same grasslands from where the mother earthworm specimens of Perionyx excavatus were collected.

\subsubsection{Determination of physicochem- ical parameters of the test media}

Soil texture, $\mathrm{pH}$ and organic carbon of the test media were determined and were recorded in Table 1.

Table 1: Physicochemical parameters of the soil media used

\begin{tabular}{|c|c|}
\hline Physicochemical Parameters & Natural Soil \\
\hline 1. Moisture Content & $61.2 \%$ \\
\hline 2. $\mathrm{pH}$ & 7.17 \\
\hline 3. Organic Carbon & $0.86 \%$ \\
\hline
\end{tabular}




\subsection{Pesticide Used}

Commercial grade pesticide namely Ustaad (10\% EC cypermethrin, United Phosphorus Limited, Gujarat, India), was used for acute as well as chronic toxicological study.

\subsection{Experimental procedure}

\subsubsection{Acute toxicity test}

The median lethal concentration of cypermethrin on Perionyx excavatus was evaluated following the 96-hr acute toxicity test method according to OECD guidelines $(14,15)$.

\subsubsection{Chronic toxicity test}

Separate bioassays were made to determine the effects of the sublethal doses $\left(25 \%\right.$ of $\mathrm{LC}_{50}$-T1 and $50 \%$ of $\mathrm{LC}_{50}$-T2) of cypermethrin on the biomass, cocoon production and specific activity of cellular enzymes acid phosphatase and alkaline phosphatase under laboratory conditions in natural garden soil. Ten pre-

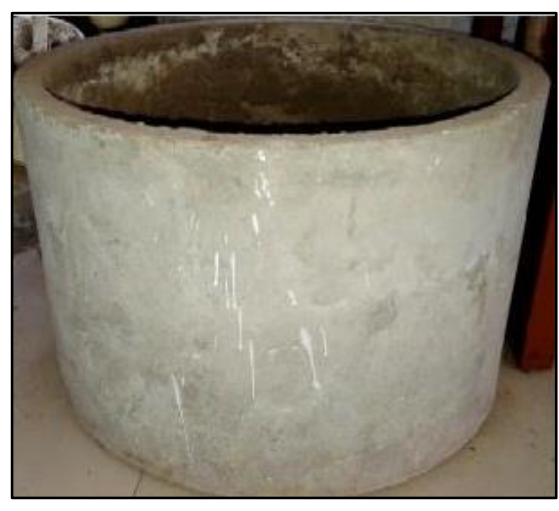

Figure 3: Culture vat of earthworms clitellate (for biomass change and cocoon production) and clitellate (for specific activity of enzymes) earthworms were released inside separate inert $(192 \mathrm{~cm} 2)$ area polyethylene boxes (Figure 4) each containing $500 \mathrm{~g}$ of sieved garden soil with $60-70 \%$ moisture content contaminated with the sublethal doses of cypermethrin. Separate replicates were made for $\mathrm{T} 1$ and $\mathrm{T} 2$ doses. The experiment was set following the procedure of OECD guidelines (14, 15). The whole set up was kept inside an environmental chamber (Figure 5) and the temperature $\left(28 \pm 0.5^{\circ} \mathrm{C}\right)$ and relative humidity $(67 \%)$ was maintained. The evaluation of change in biomass, cocoon production was performed as per OECD guidelines $(14,15)$, and change in specific activity of acid and alkaline phosphatase was evaluated following the spectrophotometric process of (20) on 28th day from the setting of the experiment. The number of cocoons was monitored at the end of each week for 4 weeks and kept in a separate box.

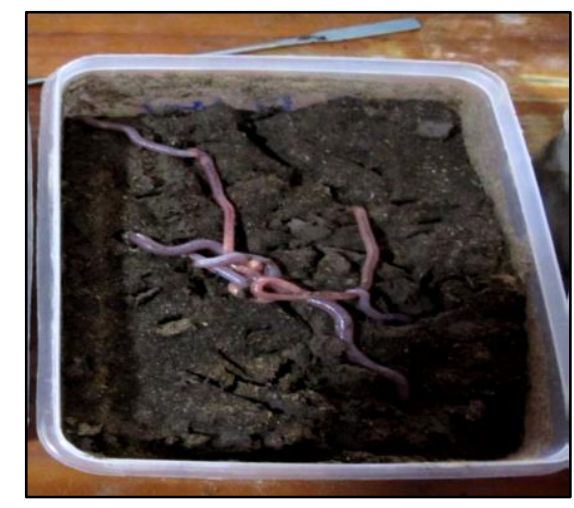

Figure 4: Earthworms in test box

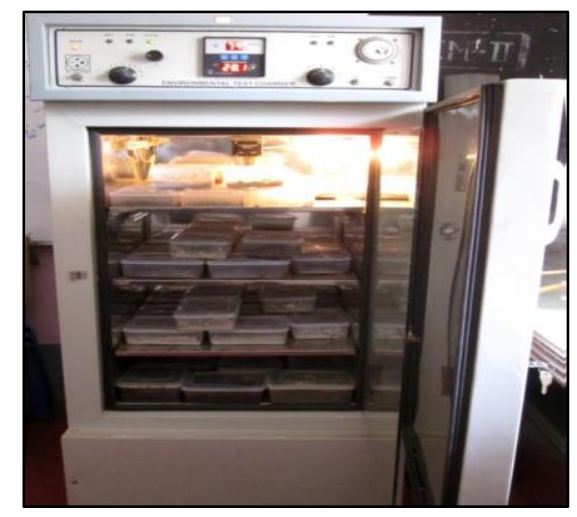

Figure 5: Environmental chamber 


\subsubsection{Statistical analysis}

The lethal concentration value was evaluated using Probit analysis software USEPA version 1.5 and for the evaluation of chronic toxicity results SPSS version 16.0 was used.

\subsection{RESULTS}

\subsection{Acute toxicity test}

The 96 hours $\mathrm{LC}_{50}$ values of cypermethrin for Perionyx excavatus was $0.012 \mathrm{mg} / \mathrm{kg}$ soil in natural garden soil.

\subsection{Chronic toxicity test}

\subsubsection{Life Cycle Toxicity}

\subsubsection{Biomass Change}

Control worms showed $71.4 \pm 3.67 \%$ increases in biomass whereas a reduction in the

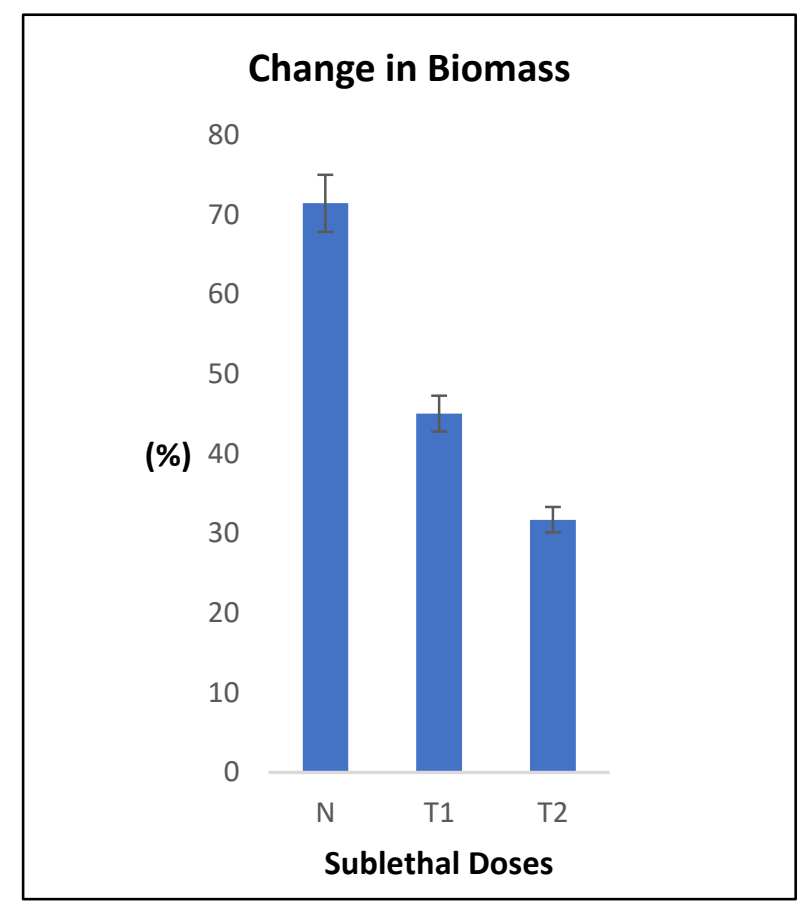

Figure 6: Change in biomass of $P$. excavatus $(\mathrm{n}=10)$ after 28 days exposure to sublethal doses (T1and T2) of cypermethrin. Control (N) has no pesticide. percentage increase of $45 \pm 3.00 \%$ of biomass was noted when exposed to $\mathrm{T} 1$ dose representing $25 \%$ of $\mathrm{LC}_{50}$ and earthworms exposed to $\mathrm{T} 2$ dose of cypermethrin $(50 \%$ of $\mathrm{LC}_{50}$ ) recorded a further reduced percentage increase, $31.7 \pm 2.53 \%$, in biomass of the test worms from their control value (Figure 6). The values of $\mathrm{T} 1$ and $\mathrm{T} 2$ doses were significantly different $(\mathrm{p}<0.05)$ from control value $(\mathrm{N})$.

\subsubsection{Cocoon production}

Cocoon production was $0.70 \pm 0.04$ cocoons/worm/week in control $(\mathrm{N})$ and was significantly reduced to $0.15 \pm 0.02$ (T1) and no cocoon production were observed in $\mathrm{T} 2(50 \%$ of $\mathrm{LC}_{50}$ ) (Figure 7).

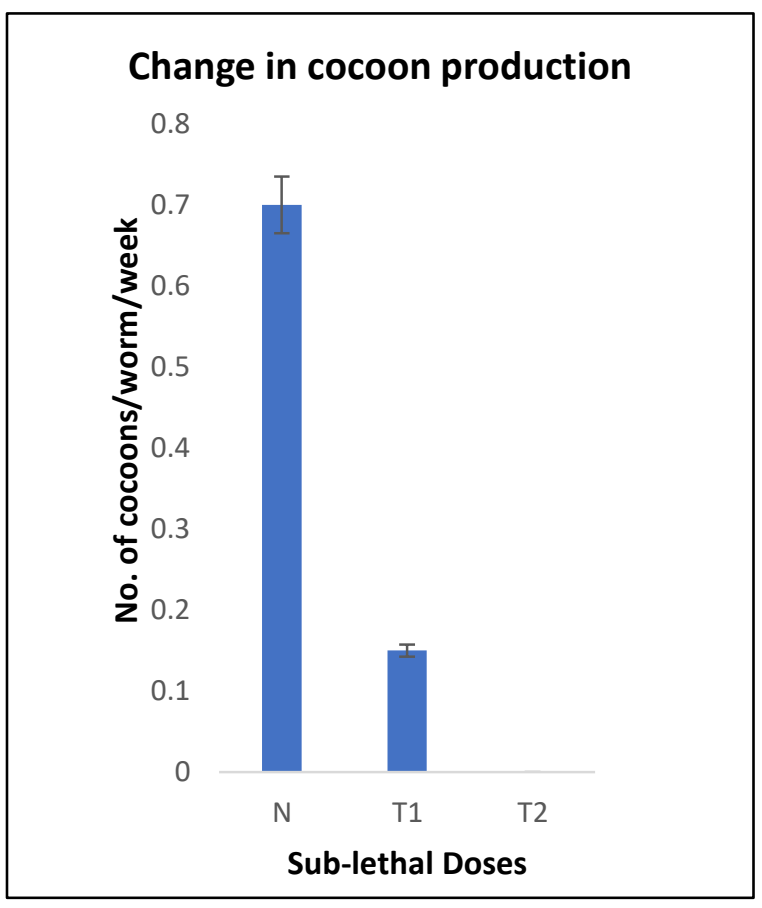

Figure 7: No. of cocoons/worm/week of P. excavatus $(\mathrm{n}=10)$ exposed to sublethal doses (T1 \& T2) of cypermethrin and the control (N) with no pesticide. No cocoons were observed in the $\mathrm{T} 2$ replicate of cypermethrin. The values of $\mathrm{T} 1$ and $\mathrm{T} 2$ doses are significantly different $(\mathrm{p}<0.05)$ from control value. 


\subsubsection{Biochemical Toxicity- Effects on specific activity of enzymes \\ 3.2.2.1 Acid phosphatase}

The acid phosphatase value in uncontaminated worms $(\mathrm{N})$ was $5.93 \pm 1.75 \mu \mathrm{gPNP} / \mathrm{mg}$ protein/ $30 \mathrm{mins}$ whereas the level was suppressed to 5.4 $5 \pm 1.80 \mu \mathrm{gPNP} / \mathrm{mg}$ protein/30mins when exposed to $\mathrm{T} 1$ dose representing $25 \%$ of $\mathrm{LC}_{50}$ and earthworms exposed to T2 dose of cypermethrin $\left(50 \%\right.$ of $\left.\mathrm{LC}_{50}\right)$ showed an elevated enzyme level of $6.57 \pm 1.90 \mu \mathrm{gPNP} / \mathrm{mg}$ protein/30mins (Figure 8). The reduced and elevated activities of enzymes in the treated replicates were not significantly different from the control replicate.

\subsubsection{Alkaline phosphatase}

The alkaline phosphatase value in uncontaminated worms (N) was $15.4 \pm 2.90$ $\mu \mathrm{gPNP} / \mathrm{mg}$ protein/30mins whereas the level was elevated to $21.8 \pm 1.05 \mu \mathrm{gPNP} / \mathrm{mg}$ protein/ 30 mins when exposed to $\mathrm{T} 1$ dose representing $25 \%$ of $\mathrm{LC}_{50}$ and earthworms exposed to $\mathrm{T} 2$ dose of cypermethrin $\left(50 \%\right.$ of $\left.\mathrm{LC}_{50}\right)$ showed a considerably elevated enzyme level of $41.6 \pm 1.1$ $0 \mu \mathrm{gPNP} / \mathrm{mg}$ protein/30mins (Figure 8). The values of $\mathrm{T} 1$ and $\mathrm{T} 2$ doses were significantly different $(\mathrm{p}<0.05)$ from control value $(\mathrm{N})$.

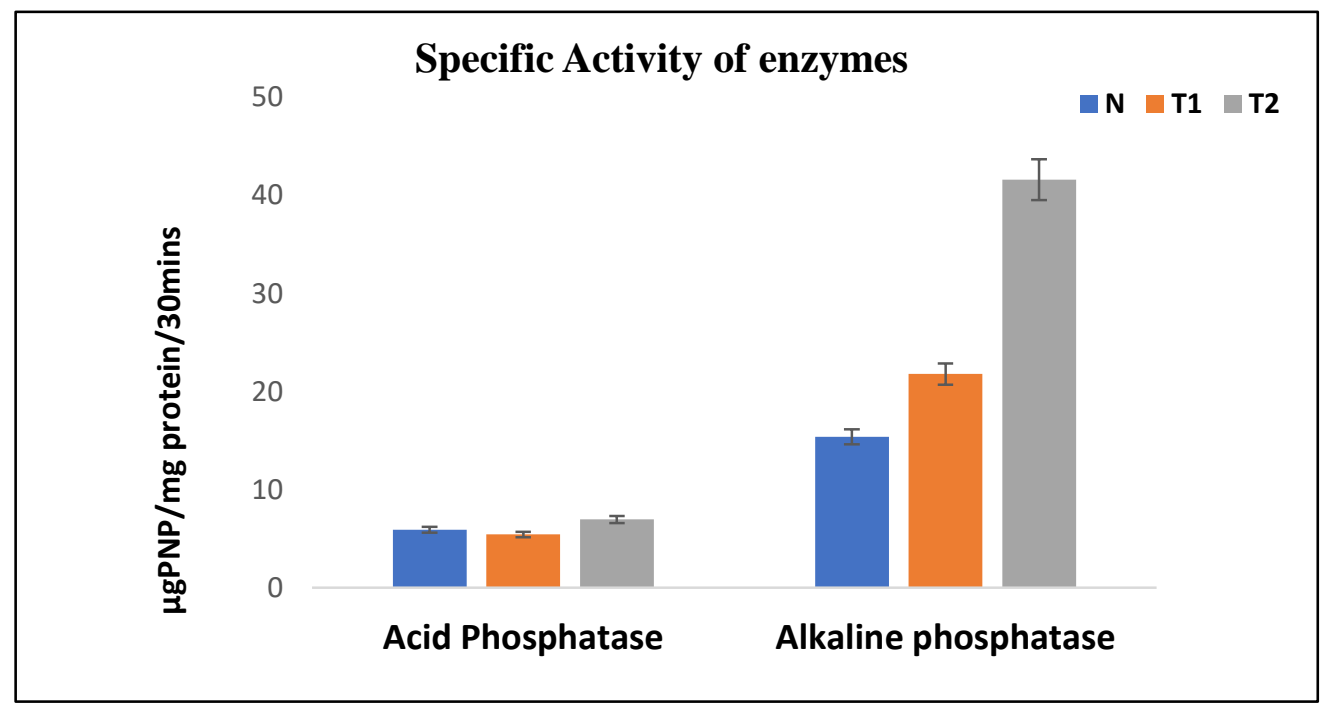

Figure 8: Specific activity of acid and alkaline phosphatase enzymes of Perionyx excavatus $(\mathrm{n}=10)$ exposed to sub lethal doses (T1 \& T2) of cypermethrin and the control (N) with no pesticide.

\subsection{DISCUSSION}

\subsection{Acute toxicity}

Based on $\mathrm{LC}_{50}$ value of the pyrethroid pesticide cypermethrin was found toxic to Perionyx excavatus in the present study.

Mostert et al. (2002), found duration dependent toxicity of the pyrethroid pesticide cyfluthrin on the earthworms of the Pheretima group as 351 $\mathrm{mg} / \mathrm{kg}$ and $330 \mathrm{mg} / \mathrm{kg}$ for $24 \mathrm{hr} \& 48 \mathrm{hr}$ respectively (21). Das Gupta et al. (2011) reported that Eisenia fetida inspite of being highly susceptible to cypermethrin $\left(\mathrm{LC}_{50}-0.054\right.$ mg kg-1), the acute toxicity value was higher than its Recommended Agricultural Dose (RAD) (22). Rosa et al. (2016) evaluated the toxicity of esfenvalerate, a neurotoxic pyrethroid pesticide, on the aquatic oligochaete Lumbriculus variegates, the organisms showing visible stress symptoms but $\mathrm{LC}_{50}$ value could not be established (23). Cang et al. (2017) carried out 14-day soil toxicity test on the earthworm Eisenia fetida and reported that a relatively less toxicity was found for lambda-cyhalothrin with an $\mathrm{LC}_{50}$ value of $560.3 \mathrm{mg}$ a.i. $\mathrm{kg}-1$ dry weight (a.i.- Active ingredient) (24). Dose dependent toxic effects of deltamethrin on mortality of $E$. fetida have also been reported by (25). Das Gupta et al. (2010) found cypermethrin to be most toxic $\left(\mathrm{LC}_{50^{-}}-0.008 \mathrm{mg} / \mathrm{kg}\right)$ than other group of insecticides to the earthworm Perionyx excavatus (26). Mosleh et al. (2003) investigated the toxicity of cypermethrin to the earthworm Aporrectodea caliginosa and recorded $28 \mathrm{~d} \mathrm{LC}_{50}$ 
value as $72.94 \mathrm{mg} / \mathrm{kg}$ (27). Fahreem et al. (2014) found cypermethrin to be most toxic to Pheretima posthuma, when compared with other pesticides, $\mathrm{LC}_{50}-0.14 \mathrm{ppm}$ (28). Singh et al. (2019) reported dose dependent toxicity of pyrethroid deltamethrin in earthworm Eudrilus eugeniae with $100 \%$ mortality (29). Tiwari et al. (2019) have shown similar results of dose dependent toxicity of cypermethrin in earthworm Eudrilus eugeniae with 100\% mortality. Accordingly, the $\mathrm{LC}_{50}$ for the cypermethrin was found to be $0.066 \mu \mathrm{g} / \mathrm{cm} 2$ (30).

\subsection{Chronic toxicity test}

\subsubsection{Life Cycle Toxicity}

\subsubsection{Biomass Change}

In the present study, P. excavatus exposed to sub-lethal doses of the pyrethroid pesticide showed significant alteration in biomass compared to its control values. Due to the high rate of soil persistence of cypermethrin or to the rapid degradation of cypermethrin in the earthworms we may conclude that the significant reduction in biomass may happen as a result of subsequent elimination of the metabolites. It could also be assumed that feeding inhibition with the earthworm due to pesticide contamination leading to reduced consumption and therefore ultimately affecting growth.

Zhou et al. (2011) reported that cypermethrin did not cause any significant reduction in the biomass of the earthworm Eisenia fetida andrei when exposed to $5 \mathrm{mg} / \mathrm{kg}$ concentration of the pesticide (31). Mosleh et al. (2003b) investigated the toxicity of cypermethrin to the earthworm Aporrectodea caliginosa and observed significant reduction in growth in all insecticide-treated worms during the 4-week test period (27). A dose dependent toxic effect of deltamethrin on growth of E. fetida was reported by (25) from sub-chronic exposures with a $42 \mathrm{~d}$ exposure period. The biomass was significantly reduced with increased pyrethroid concentrations. Rosa et al. (2016) studied a significant decrease in biomass per worm of the aquatic oligochaete Lumbriculus variegatus, with a no observed effect concentration (NOEC) value of $2.34 \mu \mathrm{g} / \mathrm{kg}$ and a lowest observed effect concentrations (LOEC) value of $36.36 \mu \mathrm{g} / \mathrm{kg}$ when exposed to the neurotoxic pyrethroid insecticide esfenvalerate (23). Gopi et al. (2014) reported a significant reduction in biomass of Eisenia fetida, when exposed to lambda-cyhalothrin. The increase in concentration of the pesticide resulted in increased biomass reduction (32). Dasgupta et al. (2015) exposed Eisenia fetida to different sub-lethal doses of cypermethrin (12.5\%, $25 \%$ and $50 \%$ of $\mathrm{LC}_{50}$ values) and reported that the worms did not show any significant alteration in change of biomass as compared to control (33).

\subsubsection{Cocoon production}

Results of the present study indicated that for Perionyx excavatus cocoon production were significantly reduced in case of cypermethrin at the lowest sublethal dose (T1) tested, while increased sublethal dose of pesticide led to no cocoon production. This may happen as a result of decreased viability of sperms in the spermatheca, alteration in cell proliferation genetic changes in spermatogonia.

Zhou et al. (2008) found that application of cypermethrin on E. fetida at rates of 5, 10, 20, 40, $60 \mathrm{mg} / \mathrm{kg}$ in OECD soil produced significant reduction in cocoon and juvenile production. Juveniles were more sensitive than the adults (34). Rosa et al. (2016) reported that in the 28day chronic test on the aquatic oligochaete Lumbriculus variegatus, a significant decrease in reproduction was observed with a NOEC value of $0.25 \mu \mathrm{g} / \mathrm{kg}$ and a LOEC value of $2.34 \mu \mathrm{g} / \mathrm{kg}$, when exposed to the neurotoxic pyrethroid esfenvalerate (23). Dasgupta et al. (2015) exposed Eisenia fetida to different sub-lethal doses of cypermethrin $(12.5 \%, 25 \%$ and $50 \%$ of $\mathrm{LC}_{50}$ values) and reported that cypermethrin did not significantly affect the cocoon production except in the highest dose where the number of cocoons was significantly reduced to $0.47 \pm 0.04$ cocoons/worm/week than the control value of $1.04 \pm 0.05$ cocoons/worm/week (33).

\subsubsection{Biochemical Toxicity- Effects on specific activity of enzymes}

\subsubsection{Acid phosphatase}

In case of Cypermethrin, the acid phosphatase activity was decreased in i.e. $\mathrm{T} 125 \%$ of $\mathrm{LC}_{50}$ value) but was elevated in $\mathrm{T} 2\left(50 \%\right.$ of $\mathrm{LC}_{50}$ value) compared to the control set i.e. N. Mosleh et al. (2003c) explained the increase in activity of 
acid phosphatase in earthworms exposed to lower doses of pesticides. The presence of phosphoric esters may elevate the enzyme activity which compensates the energy requirement of the organism to counter stress situation (35). Ahmed et al. (2004) noticed that cypermethrin treated beetles also showed an increase in acid phosphatase activity (36). Banerjee et al. (2003) found that Schizodactylus monstrosus treated with pyrethrum showed significant increased acid phosphatase activity after pyrethrum treatment in both brain and ventral nerve cord with ganglia compared with the controls (37).

\subsubsection{Alkaline phosphatase}

In case of cypermethrin, the alkaline phosphatase activity was significantly elevated in both the sublethal doses, i.e. T1 $\left(25 \%\right.$ of $\mathrm{LC}_{50}$ value) and $\mathrm{T} 2$ (50\% of $\mathrm{LC}_{50}$ value) compared to the control set i.e. N. Ahmed et al. (2004) noticed that cypermethrin treated beetles showed no changes in alkaline phosphatase activity (36). Dasgupta et al. (2015) exposed Eisenia fetida to different sub-lethal doses of cypermethrin $\left(12.5 \%, 25 \%\right.$ and $50 \%$ of $\mathrm{LC}_{50}$ values) and reported that activities of the enzyme alkaline phosphatase of Eisenia fetida were significantly elevated in all the three treatments except in $12.5 \%$ of $\mathrm{LC}_{50}$ values where the elevation was statistically insignificant in comparison to control (33). Murphy and Porter, (1966) explained that, the observed rise in alkaline phosphatase activity seen in the present study may be the indication of an adaptive rise in the enzyme activity to persistent stress (38). It has also been reported that the rise in the alkaline phosphatase level may be related to resistance of the organism towards the insecticide and the level of pathological and physiological damage caused to the particular organism $[39,40]$.

\subsection{CONCLUSION}

In natural environment, cypermethrin exist in different forms and therefore its impact on the organisms specially earthworms may be significant depending on their chemical nature, structure and mechanism of action imposing a serious threat to the life of these organisms. In the present study, cypermethrin has altered the activity of acid and alkaline phosphatase along with changes in life cycle parameters. This indicates the toxic potential of cypermethrin for the tested organism. The effects observed were tissue specific and in dose dependent manner. Such changes in pesticide contaminated environment may adversely affect the survival of an eco-friendly non target organism, earthworm. At the same time these changed parameters can be used as an essential tool to detect pesticide pollution in agro-ecosystems.

\subsection{ACKNOWLEDGEMENTS}

We thank the Principal, Raja N.L. Khan Women's College, Midnapore for providing necessary laboratory facilities and the teaching and nonteaching staffs for their support and thankfully acknowledge University Grants Commission, New Delhi for their financial support.

\subsection{CONFLICT OF INTEREST}

The authors have no conflict of interest regarding the research content of the article.

\subsection{REFERENCES}

1. van Gestel CAM, Koolhaas JE, Hamers T, van Hoppe M, van Roovert M, Korsman C, Reinecke SA. Effects of metal pollution on earthworm communities in a contaminated floodplain area: linking biomarker, community and functional responses. Environ. Pollut. 2009; 157:895-903.

2. Ali AS, Naaz I. Earthworm biomarkers: the new tools of environmental impact assessment. Biosci. Biotechnol. Res. Commun. 2013; 6:163-169.

3. Handrix PF. Soil fauna, in: M.E. Sumner (Ed.), Handbook of Soil Science. Section C. Soil Biology and Biochemistry. Washington D C: Boca Raton-LondonNew York; 2000.

4. Jadhav SS, David M. Effect of flubendiamide on morphology, avoidance behaviour and acetylcholinesterase activity in earthworm Eudrilus eugeniae. Int. J. Pharm. Pharm. Sci. 2017; 9:233-238.

5. Eriksen-Hamel, NS, Whalen JK. Impacts of earthworms on soil nutrients and plant growth in soybean and maize agroecosystems. Agric. Ecosyst. Environ. 2007; 120: 442-448.

6. Chen J, Saleem M, Wang C, Liang W, Zhang Q. Individual and combined effects of herbicide tribenuron-methyl and fungicide tebuconazole on soil earthworm Eisenia fetida. Sci. Rep. 2018; 8:2967.

7. Narra MR, Begum G, Rajender G, Rao JV. Toxic impact of two organophosphate insecticides on biochemical parameters of a food fish and assessment of recovery response. Toxicol. Ind. Health. 2011; 28:343-352.

8. Tiwari RK, Singh S, Pandey RS. Assessment of the acute toxicity of chlorpyrifos and cypermethrin to Heteropneustes fossilis and their impact on acetylcholinesterase activity. Drug Chem. Toxicol. $2017 ; 20: 1-8$ 
9. Bradberry, SM, Cage SA, Proudfoot AT, Vale JA. Poisoning due to pyrethroids. Toxicol. Rev. 2005; 24(2): 93-106.

10. Smith TM, Stratton, GW. Effects of synthetic pyrethroid insecticides on non-target organisms. Residue Reviews. 1986; 97: 93-120.

11. Wardhaugh KG. Insecticidal activity of synthetic pyrethroids, organophosphates, insect growth regulators, and other livestock parasiticides: an Australian perspective. Environ. Toxicol. chem. 2005; 24 (4): 789-796.

12. Goulart M, Callisto M. Bioindicators de qualidade de aguacomoferramentaemestudos de impactoambiental. In: Revista da FAPAM. 2003; 2(1).

13. Miller GT. Sustaining the Earth. 6th edition. Thompson Learning, Inc. Pacific Grove, California; 2004.

14. OECD, Test No. 207: Earthworm, Acute Toxicity Tests, OECD Guidelines for the Testing of Chemicals, Section 2, OECD Publishing. Paris; 1984.

15. OECD (Organization for Economic Co-Operation and Development). Guidelines for testing of chemicals No 222, Earthworm Reproduction Test (Eisenia fetida/andrei). OECD, Paris, France; 2004.

16. Julka JM. The Fauna of India and Adjacent Countries: Megadrile: Oligochaete (Haplotaxida: Lumbricina: Megascolecidae: Oligochaetida). Zoological Survey of India, Calcutta; 1988.

17. Chanda GK, Dey BD, Pati BR, Chakraborty SK. Earthworm diversity of Midnapur District. West Bengal, India. J. Natcon. 2003; 15(1): 17-30.

18. Coleman DC, Crossley DA. Jr, Hendrix PF. Fundamentals of soil ecology, 2nd edition. Academic Press, San Diago, C.A; 2004.

19. Ismail SA. Vermicology-The biology of Earthworms. Orient Longman. India; 1997.

20. Walter K, Schutt C. Acid and alkaline phosphatase in serum. In: Bergmeyer, H. U. (ed.), Verlag Chenie Weinheim, Methods of Enzymatic analysis. Academic Press Inc, New York; 1974.

21. Mostert MA, Schoeman At. S, van der Merwe M. The relative toxicities of insecticides to earthworms of the Pheretima group (Oligochaeta). Pest Mang. Sc. 2002; 58(5): 446-450.

22. Das Gupta R, Chakravorty PP, Kaviraj A. Susceptibility of epigeic earthworm Eisenia fetida to agricultural application of six insecticides. Chemosphere. 2011; 84(5): 724-726.

23. Rosa R, Bordalo MD, Soares AMVM, Pestana, JLT. Effects of the Pyrethroid Esfenvalerate on the Oligochaete, Lumbriculus variegates. Bull. Env. Cont. and Toxicol. 2016; 96(4): 438-442.

24. Cang T, Dai D, Yang G, Yu Y, Lv L, Cai L, Wang Q, Wang Y. Combined toxicity of imidacloprid and three insecticides to the earthworm, Eisenia fetida (Annelida, Oligochaeta). Env. Sc. And Poll. Res. 2017; 24(9): 8722-8730.

25. Shi Y, Shi Y, Wang X, Lu Y, Yan S. Comparative effects of Lindane and deltamethrin on mortality, growth, and cellulase activity in earthworms (Eisenia fetida). Pest. Biochem. And Physio. 2007; 89(1): 31-38. 26. Das Gupta R, Chakravorty PP, Kaviraj A. Studies on Relative Toxicities of Six Insecticides on Epigeic Earthworm, Perionyx excavatus. Bull. Env. Cont. and Toxicol. 2010; 85(1): 83-86.
27. Mosleh YY, Ahmed MT, Ismail S, Ahmed YM. Comparative toxicity and biochemical responses of certain pesticides to the mature earthworm Aporrectodea caliginosa under laboratory conditions. Environ. toxicol. 2003 b; 18: 338-46.

28. Fahreem M, Ali SA, Alam S, Khan MF. Evaluation of toxic effect of common pesticides cypermethrin, imidacloprid and Neem (Azadirachta indica) fruit extract on earthworm Pheretima posthuma. Int. J. Adv. Res. 2014; 2(11): 262-271.

29. Singh S, Tiwari RK, Pandey RS. Acute toxicity evaluation of triazophos, deltamethrin and their combination on earthworm, Eudrilus eugeniae and its impact on AChE activity. Chem. and Ecol. 2019; 1-13. 30. Tiwari RK, Singh S, Pandey RS. Assessment of acute toxicity and biochemical responses to chlorpyrifos, cypermethrin and their combination exposed earthworm, Eudrilus eugeniae. Toxicol. Rep. 2019; 6:288-297.

31. Zhou S, Duan C, GiMichelle WH, Yang F, Wang X. Individual and combined toxic effects of cypermethrin and chlorpyrifos on earthworm. J. Env. Sc. 2011; 23(4): 676-680.

32. Gopi RA, Satyavani G, Shanmugasundaram R, Balakrishna Murthy P. Acute Toxicity Evaluation of Expired Pesticides on Earthworm Eisenia fetida. Int. J. Env. Sc. 2014; 4(6): 1121-1128.

33. Dasgupta R, Sanyal S, Chakravorty PP. Chronic Toxicity of Cypermethrin, A Pyrethroid Insecticide to Epigeic Earthworm Eisenia Fetida. Int. J. Curr. Res. 2015; 7(7): 17693-17696.

34. Zhou C, Duan X, Wang WHG, Michelle Z Yu, Fu H. Assessing cypermethrin-contaminated soil with three different earthworm test methods, J. Environ. Sci. 2008; 20(11): 1381-1385.

35. Mosleh YY, Paris-Palacios S, Couderchet M, Vernet G. Effects of the herbicide isoproturon on survival, growth rate, and protein content of mature earthworm (Lumbricus terrestris $L$.) under laboratory conditions. Environ. Toxicol. 2003 c; 18: 1-8.

36. Ahmed S, Mushtaq Saleem A, Shahzad RK. Effect of cypermethrin (10EC) and bifenthrin (10EC) on levels of acid and alkaline phosphatases in a strain of Tribolium castaneum (Herbst) (Coleoptera: Tenebrionidae). Pak. Entomol. 2004; 26(1): 47-52. 37. Banerjee U, Mandal S, Choudhuri DK.Quantification of acetylcholinesterase, acid and alkaline phosphatases in the central nervous system of Schizodactylus monstrosus, (schizodactylidae:orthoptera). Neurochem. Int. 2003; 6(3): 383-386.

38. Murphy SD, Porter S. Effects of toxic chemicals on some adaptive liver enzymes, liver glycogen and blood glucose in fuster rats. Biochem. Pharmacol. 1966; 15: 1655-1676.

39. Gupta RC, Malik JK, Paul GS. Acute Toxicity Study: Fenitrothion induced biochemical changes in Male Rats. Pharmacol. 1985; 13:173-184.

40. Srinivas R, Udikari SS, Jayalakshmi SK, Sreeramulu K. Identification of Factors Responcible for Insecticid Resistance in Helicoverpa armigera (Hubner). Resist. Pest Manag. New. 2003; 13(1): 59-64. 